\title{
ANT LARVAE OF THE SUBFAMILY CERAPACHYINAE
}

\author{
By George C. Wheeler \\ Department of Biology, University of North Dakota
}

The Cerapachyinae are a neglected group of ants even among myrmecologists. This may be attributed to a combination of factors; the subfamily is a small one, about one hundred species; all species are rare and sporadic; their colonies are small; nearly all are tropical; they have no spectacular habits or bizarre structures; they are of no economic importance.

Nevertheless, they are a very interesting group phylogenetically, since they show both doryline and ponerine affinities. In fact, they have been included in both subfamilies. Forel in 1893 first recognized the group of genera as a tribe and placed it in the Ponerinae. In 1895 Emery transferred it to the Dorylinae. After protests from Forel and Wheeler he returned it in 1913 to the Ponerinae as the Section Prodorylinae. Wheeler considered the group to be intermediate between the Dorylinae and the Ponerinae and in 1920 elevated it to the rank of subfamily. It is especially significant here that he used larval as well as adult characters to justify this change.

In view of the neglect just mentioned, it is surprising that so many cerapachyine larvae are known: six species representing four of the eight genera.

\section{Subfamily Cerapachyinae Forel}

Elongate and very slender; subcylindrical; arcuate, i.e., the whole body rather evenly curved ventrally. Segmentation distinct. Spiracles small. Vestigial legs present or absent. Head small; at the anterior end. Mouth parts large and prominent. Head hairs few, short and nearly always simple. Antennae moderately large, with two or three sensilla. Labrum a thick flap, usually small. Mandibles rather feebly sclerotized; typically long and slender; base moderately stout; distal two-thirds narrow and thin; tapering to an apex which is slightly curved backward and medially; medial border serrate. Maxillae lobose; mostly rather long and round-pointed; palp small, a cluster of three to six sensilla or a low elevation bear- 
ing sensilla or a short obtuse projection bearing sensilla; galea a slender conical projection bearing a single apical sensillum. Labium large and prominent; palp a cluster of three to five sensilla, sometimes slightly elevated. Opening of sericteries mostly well developed. Trophorhinium poorly developed or absent.

Emery (1911) describes the larvae (under Section Prodorylinae of the Subfamily Ponerinae) as "uniformément poilues, sans tubercules piligères" (p. 4) and "à peu près cylindrique (comme la larve d'Eciton) revêtue de poils courts et san tubercules piligères" (p. 5).

Wheeler, 1903, pp. 208-209: "What light do these few observations, together with those recorded in my previous paper, shed on the affinities of the Cerapachyi to the Ponerinae on the one hand and the Dorylinae on the other? ... The following characters [of Cerapachys augustae] are common to both Dorylinae and Ponerinae:1. The method of carrying the larvae is common to forms like Eciton and Leptogenys. 2. The larva is intermediate between that of Eciton and Stigmatomma. It is covered with shorter, less flexuous, and less abundant hairs than the latter and in these particulars resembles the larvae of Eciton."

Wheeler, 1920: "During the past year a study of ant-larvae, representing more than hundred genera and many subgenera of all five subfamilies, has convinced me that Emery was right in 1899, when he regarded the Pseudomyrminae as constituting an independent subfamily. I am also of the opinion that the Cerapachyini should be removed from the Ponerinae and raised to the rank of an independent subfamily, between the Dorylinae and the Ponerinae" (p. 46). "A study of the larvae of the Cerapachyini shows that they are extremely like the larvae of the Dorylinae. This was noticed by Emery in his observations on the larva of Acanthostichus serratulus (1899). The mandibles are small, narrow, pointed and rather feebly chitinized, and I have failed to find a trophorhinium in either group. Apparently the young are fed only on soft food" (p. 50). On page 48 he states that the larvae of the Cerapachyinae are exceptional in not having a beautifully developed trophorhinium.

Wheeler, 1922, p. 52: "The larvae are extremely like those of the Dorylinae; they are elongate and almost cylindrical, uniformly covered with short hairs, and without piliferous tubercles. The mandibles are small, narrow, pointed, and rather feebly chitinized, and I have failed to find a trophorhinium, or triturating organ in the mouth. Apparently the young are fed only on soft food." 


\section{Tribe Cerapachyini Forel \\ Genus Eusphinctus Emery}

Diameter greatest at the sixth abdominal somite decreasing gradually toward the anterior end (except for a slight enlargement of meso- and metathorax in mature larvae) and more abruptly toward the posterior end. No leg vestiges. Hairs rather numerous, uniformly distributed, short and bifid. Cranium about as long as its greatest breadth; broad above, narrowed below. Head hairs simple (except one or two pairs which are bifid) and minute. Labrum small, not covering the bases and tips of mandibles; about twice as broad as long; slightly narrowed distally; a few sensilla on the anterior surface near the distal border; central cluster of sensilla on the posterior surface. Maxillary palp a short stout peg. Labium with a few spinules.

Eusphinctus steinheili Forel.-Figure 1. Elongate, slender, subcylindrical, arcuate (i.e., rather evenly curved ventrally). Diameter greatest at the sixth abdominal somite; decreasing gradually toward the anterior end (except in mature specimens in which there is a slight enlargement of the meso- and metathorax) and more abruptly toward the posterior end which is round-pointed. Anus ventral. Anterior portion of prothorax constricted rather abruptly to form a sort of wedge-shaped neck, which is naked except for a few ventral hairs. Ten differentiated somites. No leg vestiges. Spiracles small. Body uniformly and rather densely covered with short bifid hairs about $0.04 \mathrm{~mm}$. long. Intersomitic membranes and anterodorsal surface of prothorax naked. Head small. Cranium about as long as its greatest breadth; broad above, narrowed below; occipital border slightly curved. Mouth parts large and prominent. Head hairs few and scattered; one or two pairs bifid, the rest simple; minute (length $0.018-0.028 \mathrm{~mm}$.). Antennae of moderate size; with two or three sensilla. Labrum a small thick flap, about twice as broad as long, slightly narrowed distally; a few sensilla on the anterior surface near the distal border; a central cluster of six sensilla on the posterior surface. Mandibles rather feebly sclerotized; long and slender; base moderately stout; distal two-thirds narrow and thin, tapering to an acute apex which is slightly curved backward and medially; distal half of medial border serrate with five or six denticles. Maxillae lobose, round-pointed, rather long; palp a short stout projection bearing five or six sensilla; galea a slender truncate cone bearing a sensillum on the apex. Labium subhemispherical; 
capping the ventral end of the gula; anterior surface with a few minute spinules in regular transverse rows (concealed behind labrum); palp a cluster of three sensilla. Opening of sericteries a long transverse slit. (Material studied: several larvae from New South Wales.)

Wheeler, 1918: "Long and slender, cylindrical and not enlarged at the posterior end, with eleven distinct postcephalic segments, all uniformly clothed with short, erect, two-branched hairs. Head small, as broad as long, with vestigial antennae and long falcate mandibles, which have finely serrate internal borders. There are few hairs on the head and these are simple, with the exception of a pair near the occipital border, which are two-branched like those on the body. The color of the larva is dull white" (p. 228). Fig. 2 shows a larva in side view, a head hair, the head in anterior view and a mandible (p. 227).

Wheeler, G. C., 1938; no leg vestiges (p. 140) ; no vestigial gonopods (p. 142).

\section{Genus Cerapachys F. Smith}

Leg vestiges small paraboloidal papillae. Body hairs simple. Head (including mouth parts) subpyriform in anterior view ; cranium transversely subelliptical; occipital border slightly curved. Head hairs short. Labrum small, not covering the bases and tips of the mandibles; breadth one and one-half times the length; constricted near the base; free border strongly curved; numerous sensilla on the free border and posterior surface; posterior surface spinulose near periphery. Maxillae with the apical half spinulose; palp a low elevation together with a contiguous papilla. Labium with spinules on the middle of the anterior surface.

Cerapachys (Syscia) cryta Mann.-Fig. 2 a-d. Anterior portion of prothorax constricted abruptly to form a short wedge-shaped neck. Vestigial legs a pair of small paraboloidal papillae on the ventral surface near the middle of the posterior border of each thoracic somite. Spiracles small. Body hairs few, very long (0.4-0.6 mm.), simple, flexuous and extremely slender; longest and most abundant near posterior end; also a very few minute $(0.013 \mathrm{~mm}$.) stiff hairs. Head (with mouth parts) subpyriform in anterior view; small; mouth parts large and prominent; cranium transversely subelliptical. Head hairs few and scattered; simple, slightly curved, short (0.036 mm.). Antennae moderately large; each with three 
sensilla. Clypeus distinct; a thick flap. Labrum a thick flap; small; broader than long; constricted near base; free border strongly curved and bearing several conspicous sensilla; posterior surface with numerous sensilla near the middle and with spinules arranged in short arcuate rows near the periphery. Mandibles rather feebly sclerotized; long and slender; base moderately stout; apical twothirds narrow, thin, curved backward and medially, and tapering to a rounded point; apical half of medial border serrate wih five or six denticles. Maxillae lobose, round-pointed, rather long; apical half spinulose, the spinules grouped in short rows; palp a low elliptical elevation (bearing two sensilla) together with a contiguous papilla (which bears an apical sensillum); galea a long slender finger-like projection bearing an apical sensillum. Labium prominent, constricted at the base; free end broadly rounded; middle of anterior surface spinulose, with the spinules arranged in short transverse rows; palp a low rounded elevation (bearing three sensilla) together with a contiguous paxilla (bearing a single apical sensillum). Opening of sericteries distinct. (Material studied: three semipupae from Fiji collected by Dr. W. M. Mann.)

Cerapachys (Cerapachys) sp.-Fig. 2e. Similar to crypta but differing in a few details. The body hairs are shorter $(0.2-0.3 \mathrm{~mm}$. long) but more abundant. The head hairs are longer $(0.054 \mathrm{~mm}$. long). The mandibles have more denticles (about a dozen on each). The maxillary palp is a low elevation bearing four sensilla. The labial palp is a low elevation bearing five sensilla. (Material studied: 10 semipupae from Borneo.)

Wheeler, G. C. 1938, p. 141: no evidence of wing rudiments.

Cerapachys (Parasyscia) augustae Wheeler.-Text fig. 1. "The larvae were extremely slender, not twice as broad behind as at the anterior end, with well-marked segmental constrictions. The head is proportionately large, with strong, acute mandibles projecting beyond the clypeal and labial regions. The maxillae are furnished with a pair of prominent sensory papillae and the labium with a well-developed duct to the spinning glands. The dorsal surface of the head as well as the whole surface of the body is covered uniformly with short, slightly curved hairs. There are no traces of tubercles of any description. Attempts to observe the method employed by the ants in feeding their larvae were unsuccessful. Once, on placing a number of eggs and young larvae of Camponotus festinatus in the nest I saw the young Cerapachys larvae feeding 


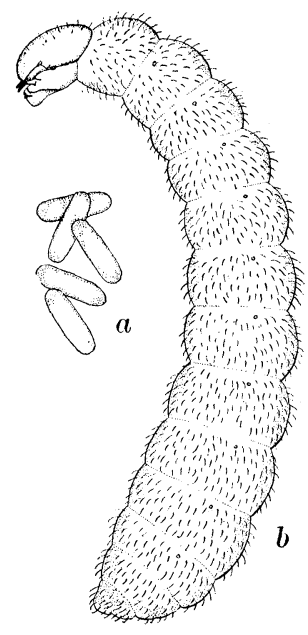

Text figure 1.-Cerapachys (Parasyscia) augustae. $a$, eggs; $b$, young larva in lateral view. (After Wheeler, 1903 and 1910. By permission of Columbia University Press.)

on the former after they had been carried under the slide by the workers. It was apparent also that the ants and their older larvae soon began to feed on the unhatched eggs and younger larvae of their own species, for the number of progeny decreased rapidly from day to day ... These larvae were carried by the ants after the manner of Eciton and Leptogenys, i.e., by the neck, with the long slender body extending back between the legs of the worker. The ants were quite as careful of their larvae as of their eggs." (Wheeler, 1903 , p. 207.) The figure of the young larva on page 206 is repeated by Wheeler (1910, Fig. 37 on p. 71) and is reproduced here (Text fig. 1) through the courtesy of Columbia University Press.

Wheeler, 1903, p. 209: “The larva probably spins a cocoon ... The larva is intermediate between that of Eciton and Stigmatomma. It is covered with shorter, less flexuous, and less abundant hairs than the latter and in these particulars resembles the larvae of Eciton."

Wheeler (1910) describes the larva of Parasyscia as "more cylindrical" than typical ant larvae (p. 72) and as "smooth, slender larvae, with a rather dense covering of hairs" (p. 233). 


\section{Genus Leoponera Mayr}

Diameter least at the first abdominal somite, increasing toward either end. No leg vestiges. Body hairs of three types: (1) long and flexuous with the tip hooked; (2) short and simple; (3) minute and simple. Cranium subhexagonal in anterior view; occipital border broadly angulate. Head hairs minute or short. Labrum large, covering most of the mandibles; width about three times the length; free border strongly curved; numerous sensilla on posterior surface. Mandibles short and stout; very feebly sclerotized. Maxillae very large and inflated; palp represented by a cluster of sensilla. No spinules on the mouth parts.

Lioponera luzuriagae Wheeler \& Chapman.-Fig. 3. Elongate, slender, subcylindrical, arcuate (i.e., rather evenly curved ventrally); diameter least at the first abdominal somite, increasing gradually toward the ends. Anus subterminal. Eleven differentiated somites. No leg vestiges. Spiracles small. Body hairs of three types: (1) long (0.1 $-0.2 \mathrm{~mm}$.) and flexuous, with the tip hooked, arranged in rows, one row of 6-12 hairs around each somite near the middle; (2) short (0.05 - $0.1 \mathrm{~mm}$.), simple, slightly curved, sparsely and irregularly distributed, except on the prothorax, where they produce a bristly aspect; (3) minute (0.013 - $0.026 \mathrm{~mm}$. long), simple, moderately numerous and uniformly distributed. Head small. Cranium subhexagonal in anterior view; a little broader than long; occipital border obtusely angulate at the middle. Head hairs very few; simple; variable in length (0.013 - $0.027 \mathrm{~mm}$.), number and location. Antennae moderately large, each with three sensilla. Labrum a large thick flap twice as broad as long and covering most of the mandibles; with its base constricted and its free border broadly rounded; numerous sensilla on posterior surface. Mandibles very feebly sclerotized; short and stout; with the basal two-thirds greatly inflated and subtriangular in anterior view; distal third very small and curved posteriorly, its apex curved medially and bluntpointed; distal half of medial border furnished with five to nine sharp denticles of various sizes and irregularly arranged. Maxillae very large, inflated, lobose; palp represented by a cluster of five sensilla; galea a small finger-like projection bearing an apical sensillum. Labium large and prominent; palp a cluster of five sensilla. (Material studied: several larvae from the Philippine Islands, collected by Dr. J. W. Chapman.)

A few of the larvae in the vial have branched hairs, but they also 
have a very wrinkled integument. This latter causes me to suspect that they have been dried out and later relaxed. At any rate, they do not differ otherwise from the larvae described above. Hence I conclude tentatively that the branching may be an artifact due to dessication. Dimorphic larvae are extremely rare among the Formicidae. Without better evidence I would not wish to consider the larva of this species dimorphic.

Whether dimorphic or not, Lioponera larvae are still the queerest of the cerapachyines. Their hooked hairs and their short broad mandibles make them decidely atypical.

The only reference to the larva of Lioponera in the literature refers to the absence of vestigial legs in L. lusuriagae (G. C. Wheeler, 1938, p. 140).
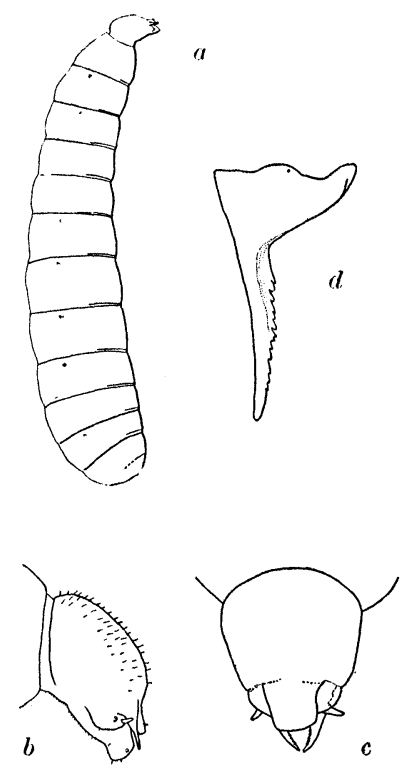

Text figure 2.-Acanthostichus serratulus. a, nearly mature larva; b, head enlarged, in profile; c, same in dorsal (sic!) view; d, mandible greatly enlarged, viewed obliquely from the side. (After Emery, 1899)

\section{Tribe Acanthostichini Emery \\ Genus Acanthostichus Mayr}

I have seen no larvae of this genus and hence must be content with Emery's description (1899, p. 4) and figures (P1. 2, figs. 5 
$a-d$ ) of $A$. serratulus (F. Smith). His description is quoted and translated below and his figures are copied as Text fig. 2 .

"Sono ... subcilindriche, coi segmenti tutti distinti: sono prive di tubercoli o altre appendici e fornite di peli numerosi, brevi e semplici; non esistono peli forcuti, ritorti o uncinati . . . Il capo, benchè più piccolo e meno convesso che nelle Ponerinae è ben staccato dal tronco, e le mandibole sono lunghe, strette, sporgenti in avanti, fuori del labbro superiore; il loro margine interno è dentellato e offre alla base una forte dilatazione. Nelle mascelle, il cono più vicino all'apice è semplice e allungato; al posto del l'altro cono, si trova una sporgenza ottusa, fornita di due piccoli tubercoli."

[Translation: Subcylindrical, with all segments distinct; no tubercles or other appendages; furnished with numerous short simple hairs; no forked, twisted or uncinate hairs. The head, although smaller and less convex than in the Ponerinae is quite distinct from the body and the mandibles are long and narrow and project forward beyond the labrum; their medial borders are denticulate and strongly dilated at the base. The subapical cone of the maxillae is simple and elongate; in place of the other cone there is an obtuse projection furnished with two small tubercles.]

\section{Discussion}

The ant larvae of the Subfamily Cerapachyinae constitute a well defined group which may be distinguished from the larvae of other subfamilies by the elongate, very slender, subcylindrical body which is rather strongly curved ventrally; by the large and prominent mouth parts; by the paucity and shortness of the head hairs; by the rather feebly sclerotized mandibles, which are typically elongate and slender and have the medial border denticulate in part; by the inconspicuousness of the labial and maxillary palps; and by the absence (or scant development) of a trophorhinium.

\section{Explanation of Plate 6}

Eusphinctus steinheili Forel, Fig. 1. - a, head in anterior view, x 97; $b$, left mandible in anterior view, $x$ 150; $c$, left mandible in side view, $x$ 150; d, body hair, x 167; e, larva in side view, x 27. Cerapachys (Syscia) crypta Mann, Fig. 2. - a, head in anterior view, $\mathrm{x} 74$; $\mathrm{b}$, head in side view, $\mathrm{x} 74$; c, two body hairs, $\mathrm{x} 100$; d, right mandible in anterior view, $\mathrm{x} 100$. Cerapachys (C.) sp. Fig. 2e, ventral view of vestigial legs, $x$ 22. Lioponera luzuriagae Wheeler and Chapman, Fig. 3, - a, head in anterior view, $x 120$; b, left mandible in anterior view, $x 387$; $c$, three body hairs, $\mathrm{x} 167$; d, larva in side view, $\times 20$. 


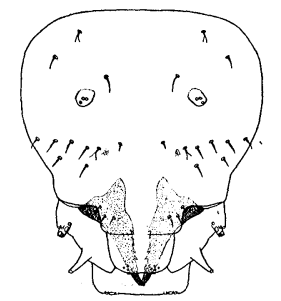

$1 a$

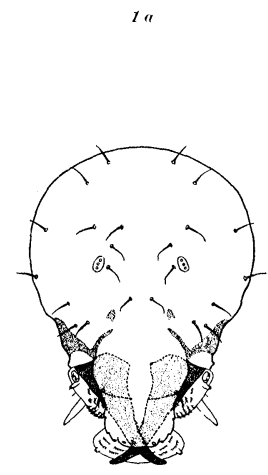

$2 a$

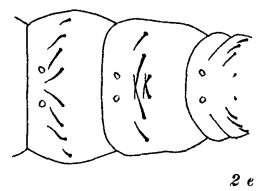

$2 e$

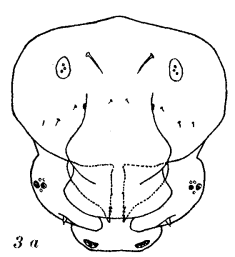

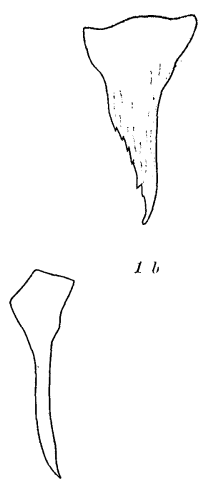
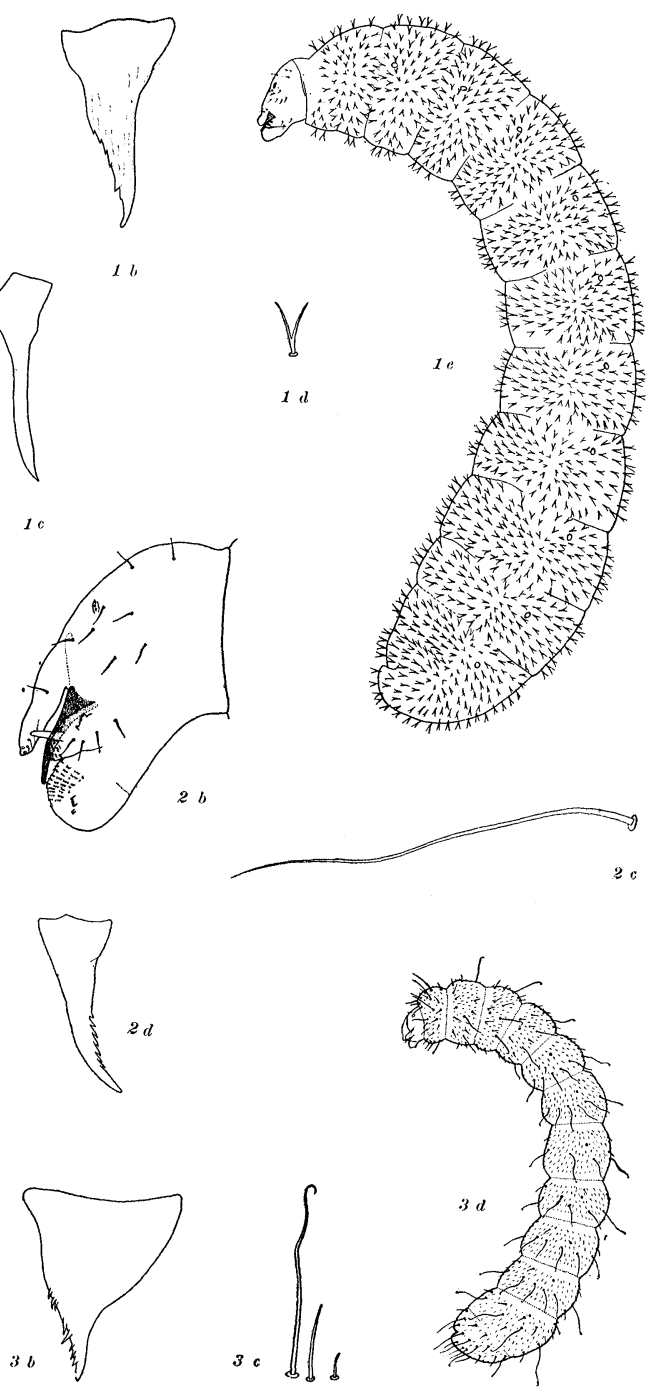

WHEELER--ANT LARVAE 
Cerapachyine larvae most nearly resemble the larvae of the Dorylinae. Both types have an elongate subcylindrical body with the head at the anterior end; rather feebly sclerotized mandibles, which are typically elongate and slender and have the medial border denticulate in part; inconspicuous maxillary palps; and the trophorhinium wanting or poorly developed. They differ in that doryline larvae are a little stouter and more nearly straight, have more hairs on the head and have smaller mouth parts.

Cerapachyine larvae also show a marked resemblance in body shape to the larvae of the ponerine genus Myrmecia. The larvae of this genus have the posterior half of the body noticeably stouter than in the Cerapachyinae, but there is a gradual attenuation from behind forward; hence there is no sharply defined "neck" which is characteristic of the higher Ponerinae. Wheeler considered the adults of Myrmecia to be eminently primitive and generalized and the larvae the most primitive of existing Formicidae.

It seems therefore that the following hypothesis might be justified. The larva of Myrmecia represents an ancestral formicid type. From this type, by differentiation into a large "body" and a slender curved "neck", the higher Ponerinae evolved. But before this differentiation occurred, a side branch was formed, the larvae of which became more attenuated posteriorly. This line led to the Cerapachyinae. A secondary offshoot from it gave rise (through straightening of the larval body) to the Dorylinae.

This study, then, supports Wheeler's conclusion (see above) that the Cerapachyinae are intermediate between the Ponerinae and the Dorylinae and also tends to confirm his diagram (1920, p. 52 ) of the phylogenetic relationships of the subfamilies of Formicidae.

\section{A Bibliography of the Larvae of the Cerapachyinae}

EMERY, C.

1899. Intorno alle larve di alcune formiche. Mem. R. Accad. Sci. Ist. Bologna (5) 8: 1-8, 2 pl.

1911. Fam. Formicidae, Subfam. Ponerinae. Genera Insectorum Fasc. 118: 125 p., 3 pl.

WHEELER, G. C.

1938. Are ant larvae apodous? Psyche 45: 139-145, 2 pl.

WHEELER, W. M.

1903. Some notes on the habits of Cerapachys augustae. Psyche 10: 205-209, 1 fig.

1910. Ants, their structure, development and behavior. $x x v+663$ p., 286 fig. New York: Columbia University Press. 
1918. The Australian ants of the ponerine tribe Cerapachyini. Proc. Amer. Acad. Arts. Sci. 53: 215-265, 17 fig.

1920. The subfamilies of Formicidae, and other taxonomic notes. Psyche 27: 46-55, 3 fig.

1922. The ants collected by the American Museum Congo Expedition. Bull. Amer. Mus. Nat. Hist. 45: 39-269, 22 pl., 76 text fig., 41 maps.

The Northernmost Extension of Bird Hippoboscidae in the New World (Diptera).-The Hippoboscidae are essentially a tropical and subtropical group of insects. In cold temperate regions the number of species is very small and most of them seem to occur only as accidental summer visitors. In the New World the 50th parallel forms about the northern limit for the family as a whole. Farther north the flies are probably not truly part of the autochthonous fauna. Among the many hundreds of North American flies I have seen in recent years, only half a dozen, all of one species, Ornithomyia fringillina Curtis, were taken in Alaska, at the following localities: Crater Mt., off "Columbia falcon"; Nelchina River, north of Mt. Witherspoon (N.W. of Valdez); Takotna, $63^{\circ} \mathrm{N}$., $165^{\circ} \mathrm{W}$, off Hudsonian spruce grouse, Canachites c. canadensis (Linnaeus); and Old Crow River, Timber Creek, Yukon. Takotna is the northernmost locality for a hippoboscid in the New World. In the eastern part of the continent these flies stay much farther south, the northernmost record there being an Ornithomyia fringillina taken by Eidmann off a junco on the Matamek River in the southern part of the Labrador Peninsula $\left(50^{\circ} 17^{\prime}\right.$ N.). Hippoboscidae of birds seem to extend farther north in Europe, where several species occur in Finland. One of them ( $O$. fringillina) has been reported also from Iceland. None are known from Greenland. Several of the common passerine birds, serving as hosts of $O$. fringillina in southern Canada and the United States, extend during the summer to the Arctic Circle and beyond, so that the virtual absence of hippoboscids from the far north is most probably due to adverse climatic conditions.-J. Bequaert, Museum of Comparative Zoology, Harvard University. 

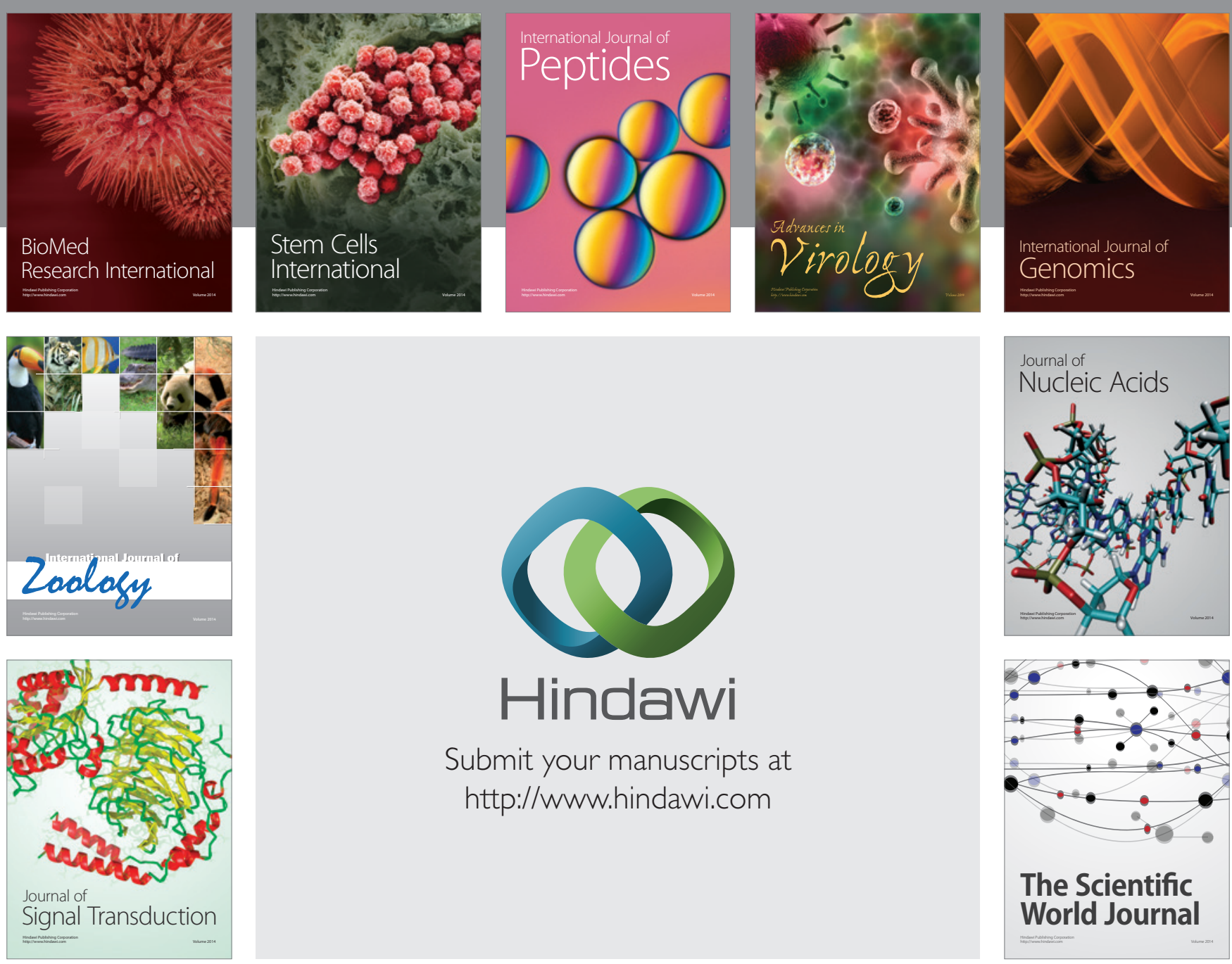

Submit your manuscripts at

http://www.hindawi.com
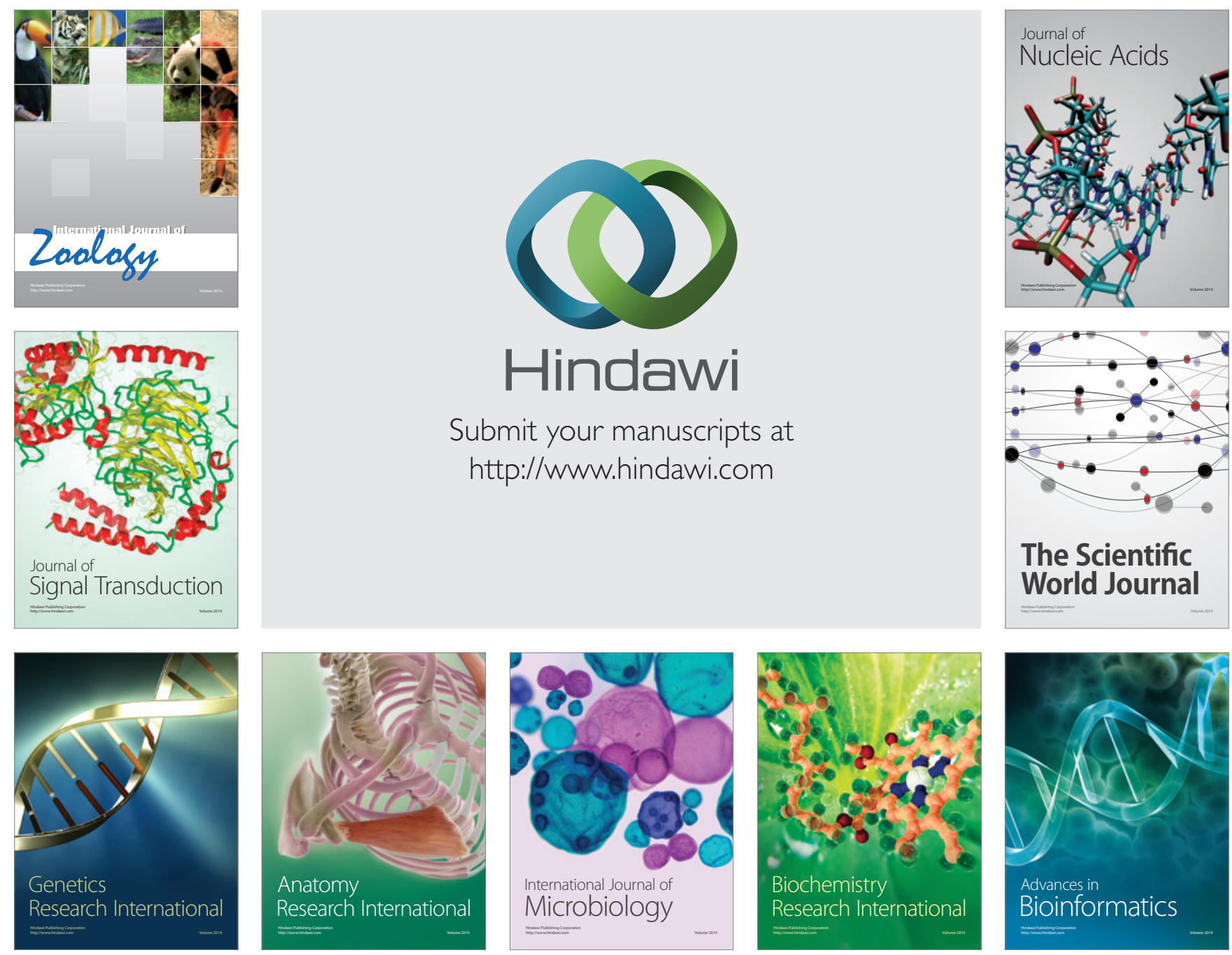

The Scientific World Journal
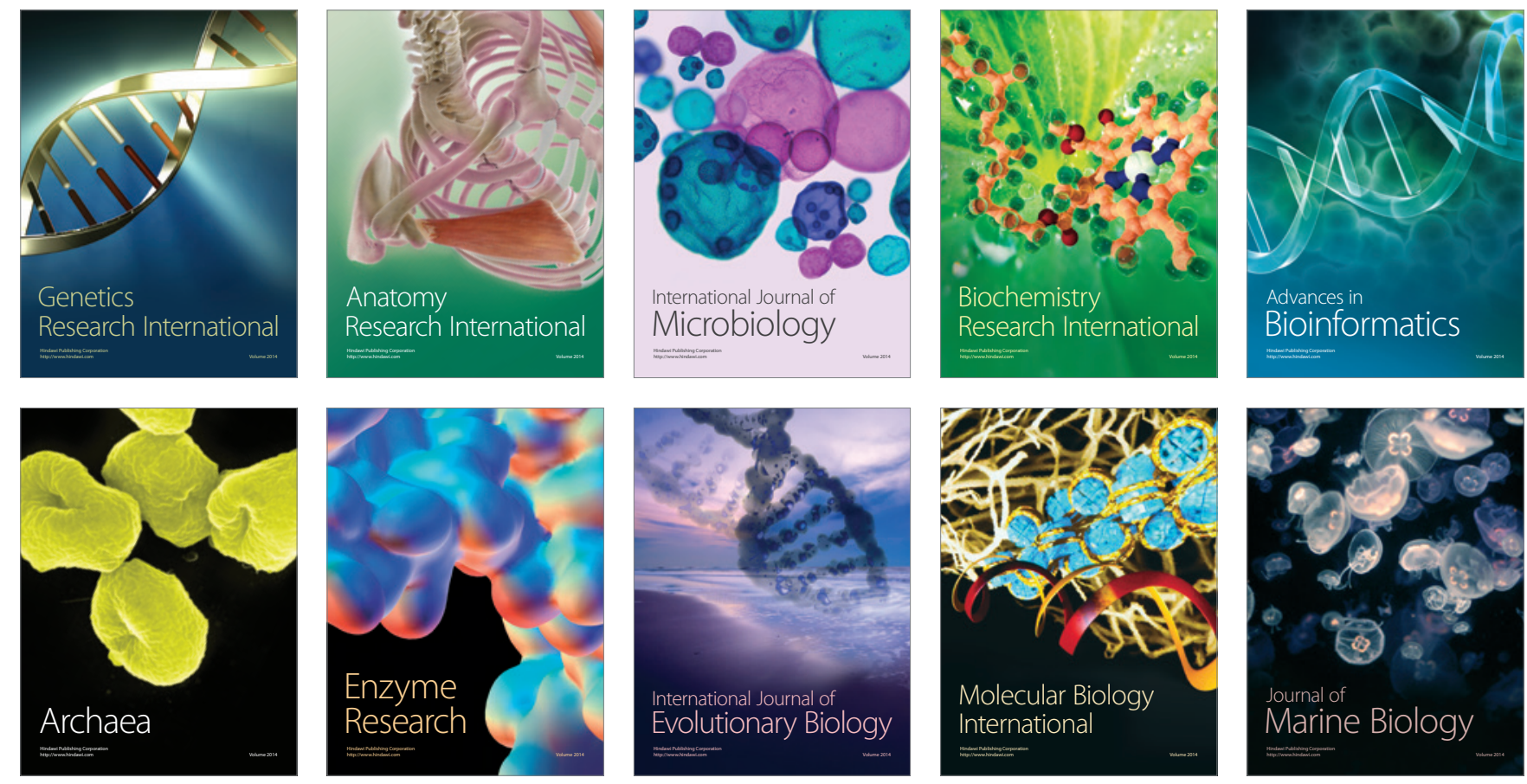